\title{
Energy-Efficiency Retrofitting Strategies for Existing Residential Building Envelope System-A Case Study in China
}

\author{
Yingqing $\mathrm{Xu}^{1}$, Guopeng $\mathrm{Li}^{1}{ }^{*}$, Jing Zhou ${ }^{2}$ \\ ${ }^{1}$ School of Architecture and Fine Arts, Dalian University of Technology, Dalian, China \\ ${ }^{2}$ Tangshan Haigang Economic Development Zone Second Middle School, Tangshan, China \\ Email: *liguopeng@dlut.edu.cn
}

How to cite this paper: Xu, Y.Q., Li, G.P. and Zhou, J. (2021) Energy-Efficiency Retrofitting Strategies for Existing Residential Building Envelope System-A Case Study in China. Journal of Building Construction and Planning Research, 9, 12-25.

https://doi.org/10.4236/jbcpr.2021.91002

Received: November 9, 2020

Accepted: March 5, 2021

Published: March 8, 2021

Copyright $\odot 2021$ by author(s) and Scientific Research Publishing Inc. This work is licensed under the Creative Commons Attribution International License (CC BY 4.0).

http://creativecommons.org/licenses/by/4.0/

\begin{abstract}
With the rapid development of urbanization, the Chinese government has put equal emphasis on construction and retrofitting. But those projects did not achieve optimal effect because of the lack of targeted and systematic design guidance system. In this study, it first analyzes existing retrofitting methods and sorts into five retrofitting types as a basis, and then, captures the combinations and permutations of retrofitting methods and materials by parts and layers to build a database. After that, it combines different kinds of approaches by hierarchical matrix method to conclude the most efficient strategy. This study also selects typical residential buildings built between 1980 and 2000 in cold climate area of Northeast China as the research objects to test the integrity and effectiveness. As the results of this paper, it provides systematic guidance and multiple performance-based retrofitting strategies of the existing residential envelope system, which can improve indoor thermal comfort with low energy consumption.
\end{abstract}

\section{Keywords}

Existing Residence, Envelope System, Hierarchical Method, Retrofitting Strategy

\section{Introduction}

With China's urbanization exceeding 53\% [1], the huge amount of housing stock accounts for more than three-quarter of the existing building, which consumes a lot of fossil fuel to meet the new standards of building performance. It is difficult to balance the thermal comfort and energy conservation, especially in the cold area. The energy-retrofitting of the envelope system accounts for $30 \%$ of the 
contribution of achieving the energy-saving goals [2]. Therefore, the performance-based retrofitting of envelope system has huge economic and environmental effects. At present, most of the retrofitting practice lacks basic data, energy-efficiency design at the early-design-stage, and evaluation standards, which leads to fuzzy results and optimal transformation effects. It is imperative to carry on energy-efficiency retrofitting on building envelope system to improve living quality and physical conditions of residential building.

Based on above problems, existing residential buildings built between the 1980 and 2000 in Northeast China are regarded as research objects, because of the intact and unified masonry construct, low construction standards, high energy consumption, and poor thermal performance. This study first captures the combinations and permutations of retrofitting methods and materials by parts and layers to build a database. Then, it focuses on combining the individual component retrofitting approaches in simulation tool to solve the compatibility of the whole envelope system and improve energy efficiency in retrofitting project. The result of this study can provide designers and related practitioners with new ideas and effective design-related decision-making strategies.

Literature review, field investigation and analysis, comparative analysis, and case analysis are also included. Figure 1 summarizes the structure of this paper.

\section{Background of Residential Building Retrofitting}

The existing research includes five parts: theory, approach, effect evaluation, retrofitting component, and construction process.

John Habraken [3] first articulated Open Building Theory which is the basis of Four Layers [4] and Six Shearing Layers of Change [5]. The development of Brand's Shearing Layers is the Adaptive Future [6] which conducted a set of surrounding layers that explain how a building and its constituent parts will change over time. Fan Yue [7] conducted research on the improvement of existing residential quality from functionality, comfort and locality.

Studies on retrofitting approach mainly based on case study by summarizing methods and technologies, such as summarizing the design methods, processes and funding sources [8]; constructing an information-based auxiliary system for

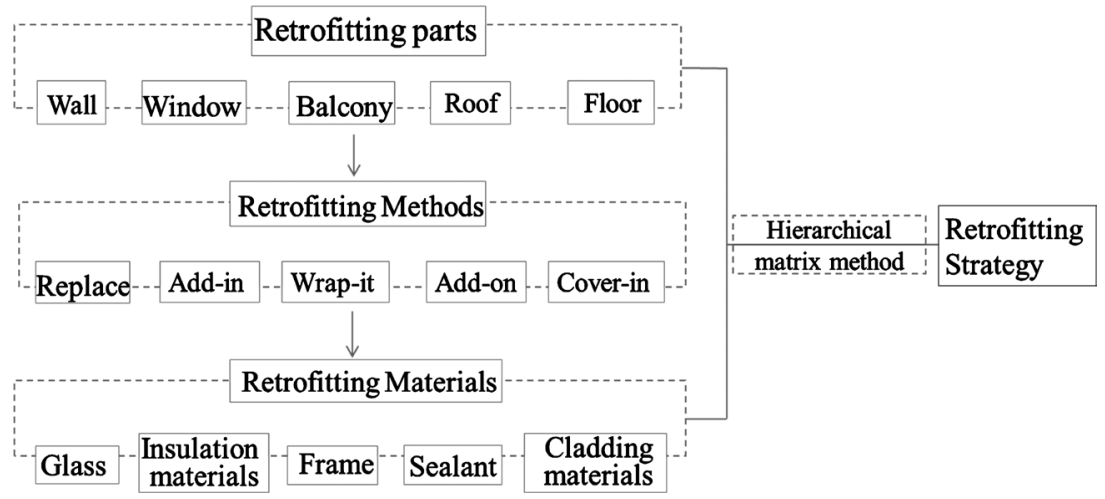

Figure 1. Research structure. 
residential pathology diagnosis and repairing [9]; establishing a double-layer interface and consensus interval technologies [10]. Although researches on retrofitting approaches which summarized by the practical cases can be a reference, it lacks pertinence and specificity model which have not formed a comprehensive and systematic strategy database for the complexity and diversity of existing buildings.

Most of the research on the retrofit effect focuses on the energy consumption reduction of individual components [11] [12]. For example, Cui [13] compared energy reduction of two conditions from the energy-saving renovation of windows during a year. Zhu [14] researched on the development of windows and balconies with structural waterproof and thermal insulation properties Module. Without overall coordination with other parts in the entire enclosure system, those strategies can only improve the energy-saving effect at a certain extent.

Energy consumption of air conditioning and maintaining indoor thermal comfort accounts for about $50 \%$ of the total energy consumption [15]. Therefore, energy-retrofitting of the envelope system is an effective measure to improve indoor comfort and physical performance [16] such as improving insulation, reducing thermal loss, and solving cold bridges. A large number of studies have shown that it can effectively reduce energy consumption and improve energy-efficiency [17] [18] by improving the insulation performance of wall [19] [20], door and window [21], roof [22] and corridor.

In terms of the construction process and effect evaluation, Häkkinen [23] proposed to use the computer-aided simulation for performance evaluation before carrying out construction transformation, which avoided the uncertainty of detection during operation.

It is shown that most of the existing residential building retrofitting studies based on practical cases and focus on individual component, lacking a comprehensive retrofitting approaches system for the entire envelope system. It is necessary to build a functionality database of envelope system that is suitable for different building conditions of the huge amount of housing stock to reduce energy consumption of maintaining thermal comfort.

\section{Retrofitting Strategy of Existing Residential Building}

\subsection{Retrofitting Parts and Layers}

According to the hierarchical approach, the envelop system is divided into five layers, including wall, window, roof, balcony, floor, each of which can be divided into more specific layers. For example, the wall and the roof can be divided into exterior surface layer, performance layer, structural layer and interior surface layer hierarchically. The floor includes interior surface layer, performance layer and structural layer (Figure 2).

\subsection{Retrofitting Strategy}

Based on the different function of every layer, retrofitting approach can be cata- 
logue and it compiles the existing retrofitting approaches into five categories (Table 1), which can be regarded as the basis to construct the hierarchical retrofitting strategies system. For example, the performance layer is embodied in improving the thermal insulation and waterproof performance of the envelop system.

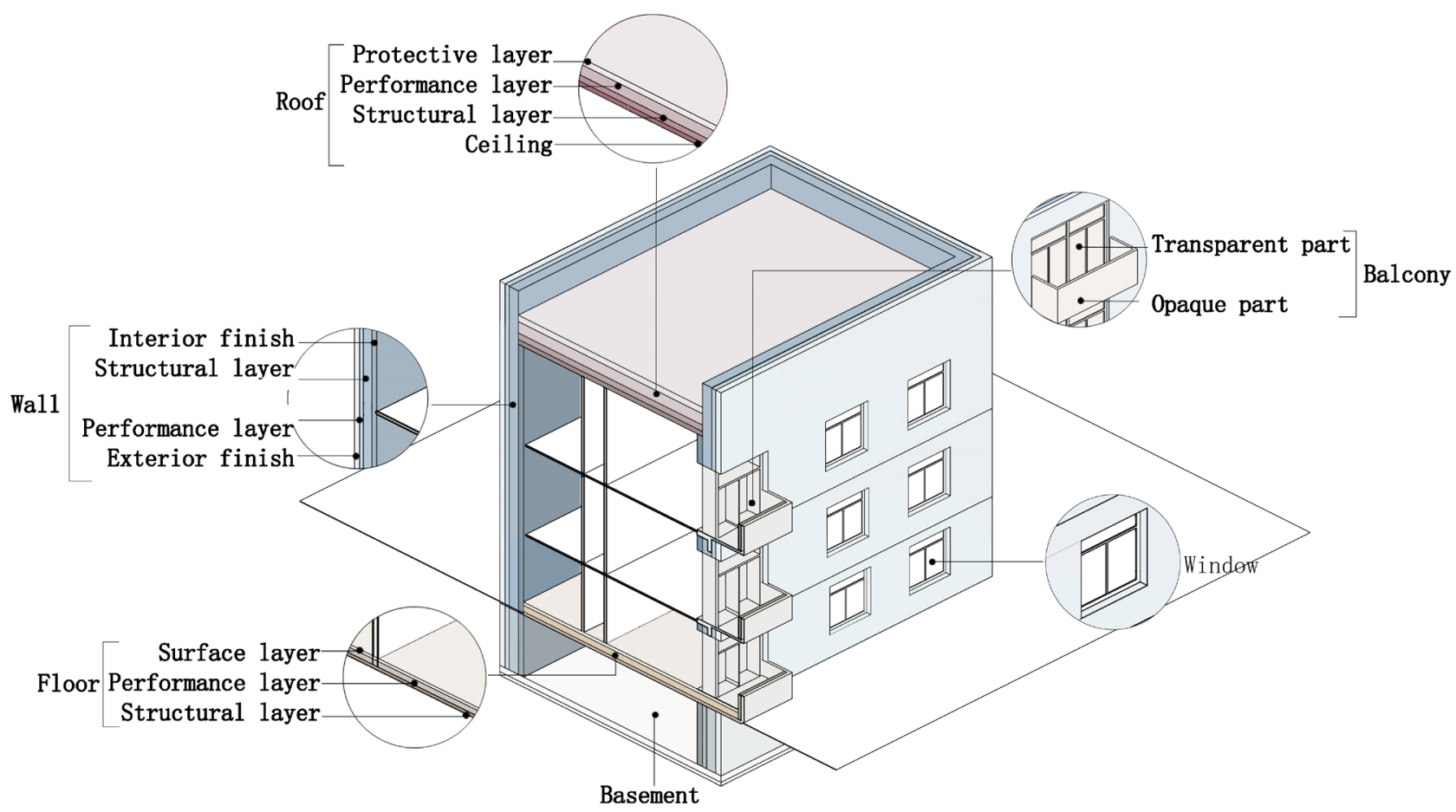

Figure 2. The parts and layers of the existing residential envelope system.

Table 1. Five retrofitting approaches of envelope system. [24]

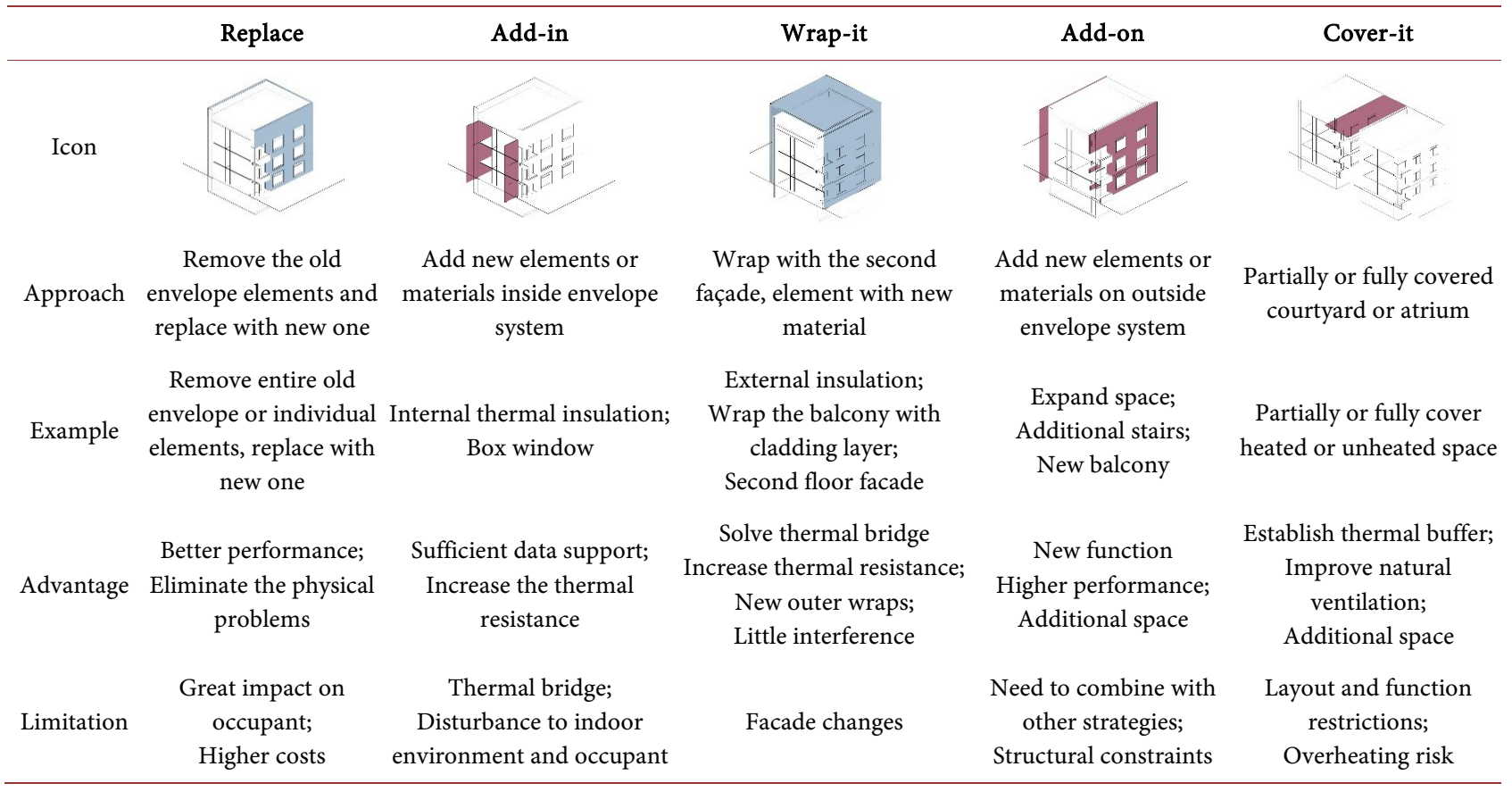


The five retrofitting approaches can be applied to different layers of the existing envelope system.

1) Wall

The wall is one of the most important components of the envelope system. It can be divided into four levels from outside to inside: exterior finish, performance layer, structural layer, and interior finish. Improving the performance of wall system can effectively reduce energy consumption that required to maintain the indoor thermal environment. It can be retrofitted by three approaches: Add-in, Replace and Add-on.

Add-in includes cavity insulation and internal insulation, applying for maintaining the original façade and monumental buildings, but it may affect indoor space and occupants living. Replace and Add-on can replace or repair the existing exterior finish to protect the performance layer (Figure 3), such as the combination of performance layer and exterior surface layer transforms to form external insulation or "ventilated vertical surface".

2) Window

As the transitional part between indoor and outdoor, the thermal loss directly caused by window accounts for about $23 \%-27 \%$ of the total amount [25], and it affects the indoor thermal comfort, lighting, ventilation and sound insulation. The performance of the window is related to the performance of the frame, glass, heat transfer coefficient $\mathrm{K}$, shading, air tightness, water tightness, and wind resistance.

The retrofitting approaches are Add-in, Replace and Add-on, including structure and materials. Add-in includes glazing upgrading and additional windows. Glass upgrading can improve performance by reinstalling high performance glass, such as Low-E glass and vacuum glass; additional windows are attaching single/double-glazed windows to the inside of existing windows to form the box window [26] [27]. Replace includes replacing the entire window with the double/three-layer window [28] of better performance and enlarging window. Add-on is to add fixed or adjustable sunshades to control solar gain and reduce cooling load according to different facade orientations.

3) Roof

The roof is an enclosure component that isolates adverse external environmental factors form the top of the building. It can be divided into exterior finish

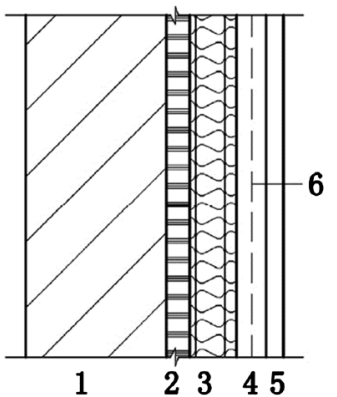
1、Base wall
2、Bonding layer
3、Insulation layer1
4.Plastering
5.Finishing layer
6、Strengthen Mesh

Figure 3. External insulation system. 
layer, performance layer, structure layer, and an interior finish layer. The performance layer, including thermal insulation layer, isolation layer (divided into waterproof layer and vapor barrier layer), bonding layer, and leveling layer, is the key retrofitting layers. The retrofitting approaches include Add-in, Wrap-it, Replace, and Add-on. The performance layer is divided into slope roof insulation and flat roof insulation according. The slope roof insulation uses Add-in and Add-on to add an insulation layer between/above/below the rafters.

Add-in is to add loose materials between the top beams and slab to form a thermal insulation layer. Wrap-it adapts the transformation of flat roof insulation, including three methods: upright insulation, inverted insulation, removal and replacement of roof panels and roof systems. It can also use both Wrap-it and Add-on to combine performance layer and exterior surface layer [29], such as roofing green plants and flat slopes.

4) Balcony

The balcony is an extension of the internal space of the building. It can be divided into the transparent part (window) and the opaque part (balcony board) according structural. It can also effectively solve the balcony thermal bridge by solving the continuity between the balcony board and the floor.

The retrofit approaches of the balcony include Wrap-it and Replace to solve thermal bridges and form thermal buffer zones. The key to solving the thermal bridge is to transform the balcony board, such as using thermal insulation materials to cover the entire balcony board; removing existing balcony and installing thermal insulation on the edge of the balcony board and replace it with a new balcony to create a thermal fracture zone. The balcony with single-layer or double-layer aluminum frame glass to form a thermal buffer zone by Wrap-it. For the top floor balcony without horizontal shading, additional high-performance glass/window can be introduced and Add-on fixed or adjustable sunshades to improve the insulation performance of the transparent part.

5) Floor

The floor can be divided into interior finish, performance layer, and structural layer. The main retrofit layer, the performance layer can also be divided into bonding layer, isolation layer, leveling layer and insulation layer. Add-in and Wrap-it can be used to effectively reduce the thermal loss from the first floor, including add insulation at the top/bottom of the floor, and the use of pressure-resistant insulation materials. If there is underground space in existing building, the basement roof is used as a load-bearing component to separate the first-floor space and the basement space. A new performance layer is added on the top of the existing floor with insulation materials (Figure 4(a)). If there is no underground space, a new performance layer is installed at the bottom of the slab by adding insulation materials (Figure $4(\mathrm{~b})$ ).

\subsection{Retrofitting Material}

There are five materials types: thermal insulation materials, glass, frames, sealants, 


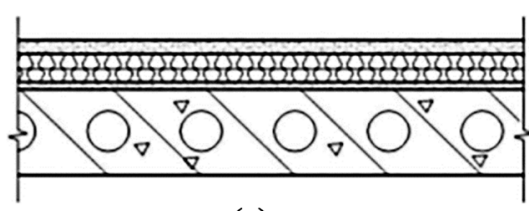

(a)
1. Surface layer

2. Performance layer

3. Original surface layer

4. Structural layer

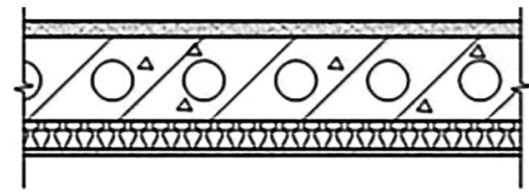

1. Surface layer

2. Structural layer

3. Performance layer 4. Protective layer

(b)

Figure 4. (a) Insulation added on the top, (b) Insulation added at the bottom.

Table 2. Retrofitting material

\begin{tabular}{|c|c|c|c|c|}
\hline Material & Description & Requirements & \multicolumn{2}{|c|}{ Material type } \\
\hline $\begin{array}{l}\text { Thermal } \\
\text { insulation } \\
\text { materials }\end{array}$ & $\begin{array}{l}\text { Materials with high thermal } \\
\text { resistance and low thermal } \\
\text { transmittance }\end{array}$ & Thermal insulation & \multicolumn{2}{|c|}{$\begin{array}{c}\text { Organic thermal insulation materials, Inorganic/mineral } \\
\text { thermal insulation materials }\end{array}$} \\
\hline Glass & $\begin{array}{c}\text { Transparent material with } \\
\text { visual permeability }\end{array}$ & $\begin{array}{c}\text { Thermal insulation, passive } \\
\text { solar heat gain, shading }\end{array}$ & \multicolumn{2}{|c|}{ Thermal insulation glazing, Low-E coating, colored glass } \\
\hline Frame & Assemble and organize glazing & $\begin{array}{l}\text { Thermal insulation } \\
\text { Air permeability }\end{array}$ & $\begin{array}{l}\text { Wood } \\
\text { Wood/aluminum } \\
\text { Aluminum alloy }\end{array}$ & $\begin{array}{c}\text { Steel, Polyvinyl Chloride (PVC) } \\
\text { Unsaturated Polyester (UP) }\end{array}$ \\
\hline Sealant & $\begin{array}{l}\text { Seal gaps } \\
\text { Prevent uncontrolled air and } \\
\text { water flows }\end{array}$ & $\begin{array}{c}\text { Thermal insulation } \\
\text { Air tightness }\end{array}$ & $\begin{array}{c}\text { Neoprene, EPDM, Flexible } \\
\text { PVC, Silica gel }\end{array}$ & $\begin{array}{l}\text { Rigid polyurethane } \\
\text { Hot melt isobutylene } \\
\text { polysulfide sealant }\end{array}$ \\
\hline
\end{tabular}

and cladding materials, among which, thermal insulation materials and multilayer glass are most important in performance improvement (Table 2). Thermal insulation materials are based on low thermal conductivity that isolates the air transformation [30] between different temperature zone. The selection of materials depends on the fire resistance, sound insulation, compressive strength, economy, constructability, environmental-friendly and application for different parts and layers.

There are some of the most common use materials including: a) organic thermal insulation materials: Expanded Polystyrene (EPS), Extruded Polystyrene (XPS), Polyurethane Rigid Foam (PU), Phenolic Foam (PF). b) inorganic/mineral with high recyclability, fire resistance and thermal insulation materials: mineral wool, rock wool, glass wool, foam mineral thermal insulation materials, aerogel [31]. In addition, the thermal resistance of the Vacuum Insulation Panel (VIP) [32] is about 10 times higher than that of the traditional polystyrene board of the same thickness, and the space restriction is very low, which is very effective in rebuilding projects.

Glass plays a key role in building performance, which provides a visual and light connection between outdoor and indoor and improves the quality of the indoor environment. The measurement index is the heat transfer coefficient $\mathrm{K}$ value and is influenced by the number of glazing layers, the depth of the cavity, the filled gas and the coating. The glass can be used in retrofitting includes: heat-absorbing glass, heat reflecting glass, multi-layer glass, Low-E glass, vacuum glass [33]. 
Upgrading of frame is mainly based on aluminum, plastic, steel and thermal bridge frames. Thermal bridge frame is a thermal insulation material that can be applied to window frame profiles specially to reduce thermal bridge including ABS (acrylonitrile-butadiene-styrene), polyethene HD, polyamide (Nylon), Polypropylene, PVC-U (polyvinyl chloride) and polyurethane. Sealant is also an important material to solve the airtight between the frame and glass, mainly including sealing strips and sealants.

Facing and cladding materials are the most directly in contact with the external condition. According to the project, budget, and expected effect, there are multiple approaches, such as cladding materials, including cement plastering that provides a hard protective with adhesives, and creating a cavity structure between the performance layer and the panel to form a ventilated facade; Gypsum board with strong water absorption, sound absorption and decoration; top paint with decoration and protection; Phase change material (PCM) [34] that can store or release energy.

\section{Case Study}

Hierarchical matrix editing method is introduced to catalogue design approaches, emphasizing the hierarchical progress in retrofitting process. It firstly formulates the hierarchical retrofitting database from the individual component retrofitting approaches. Then, transform the individual component system to the overall retrofitting strategies of the envelope system by layers, realizing the integration of technologies from single to diverse.

\subsection{Case Introduction}

This study has made field surveys and data collection work about existing residential building retrofitting in typical cities in the Northeast China. It is one of the eight earliest industrial areas in China, which has important historical, cultural and memory values. Since the early 1950s, it has been taking the lead in responding to various housing policies, and it was the place where housing design standards and implementation were first established. According to the preliminary survey carried out in typical cities in Northeast China, such as Shenyang, Harbin, Changchun and Dalian, the residential evolution of Dalian can profoundly reflect the social and economic changes in China. This study takes Building-21 of the $10^{\text {th }}$ Group of Wencuixuan community, Dalian as an example. The hierarchical matrix editing method is introduced to solve the compatibility of individual components of different layers. Firstly, building-21 is divided into five layers by part (Figure 5). Then, a basic information database is established to form the first hierarchical editing layer (Table 3), including location, original information, current statue information, plan and et al.

\subsection{Retrofitting Strategy}

Based on the first hierarchical editing layer, collecting the corresponding retrofitting approaches of each layer to form the second hierarchical editing layer (Table 4). 


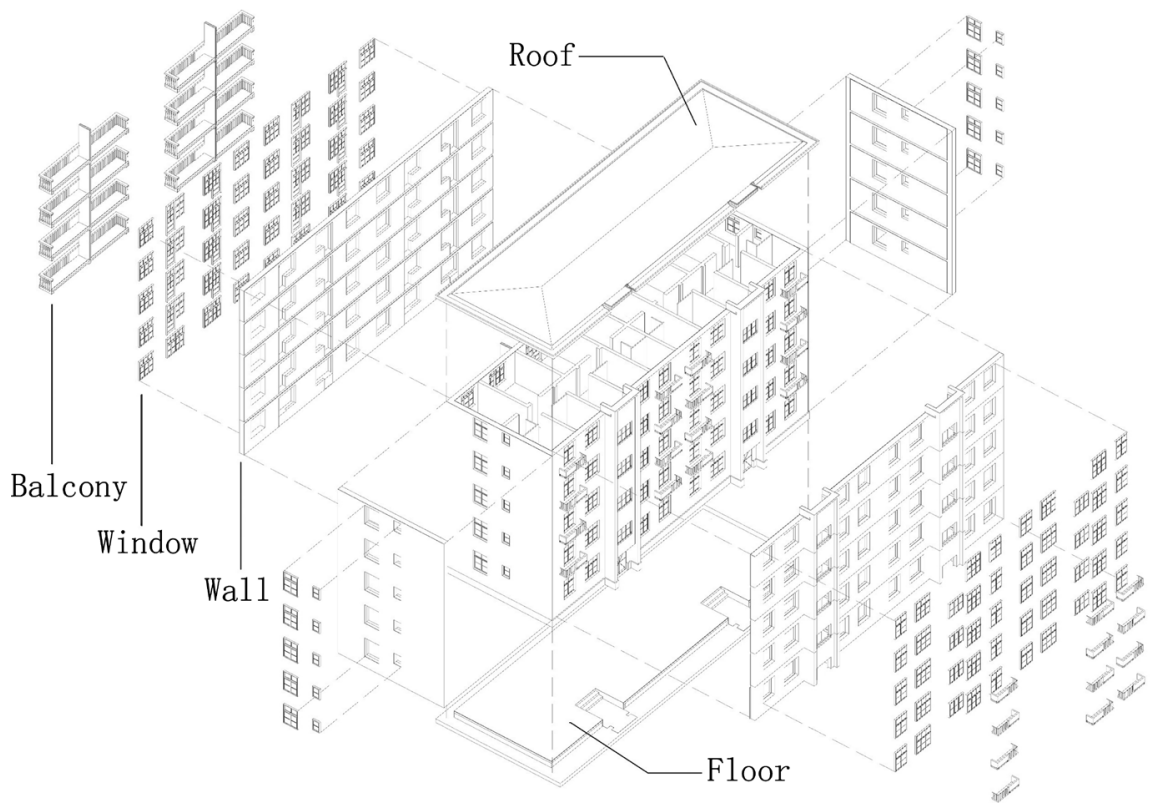

Figure 5. Layer of building-21 envelope system.

Table 3. The first hierarchical editing layer: Building-21 envelop system information survey.

\section{Sample selection: Group-10, Building-21}

Location: Intersection of Wuyi Road and Wenjing Street, Shahekou District, Dalian

Construction year: 1981-1983

Scale: 20 households

Total construction area: $1205 \mathrm{~m}^{2}$

Terrain: gentle slope

Construction company: Dalian Institute of Technology

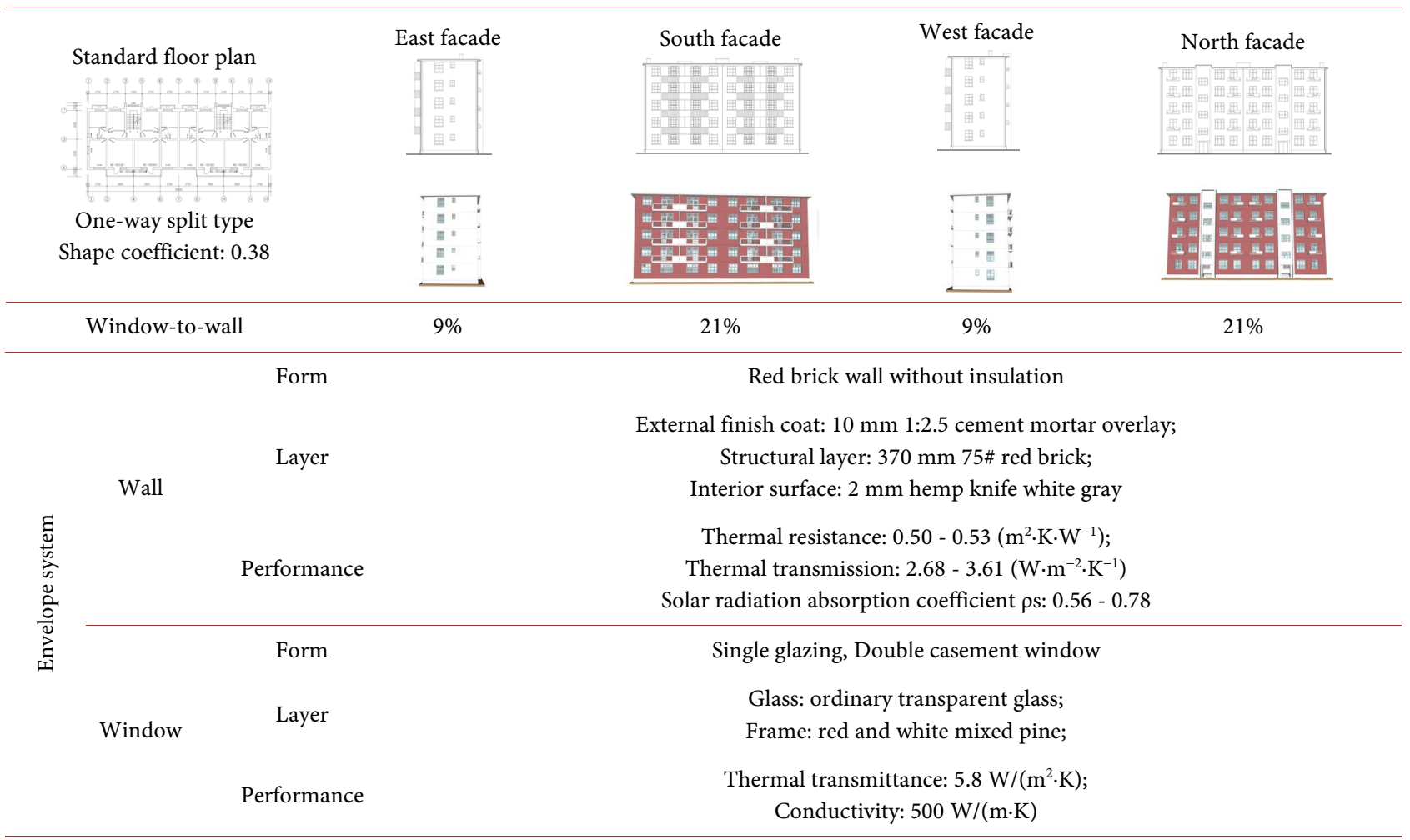




\section{Continued}

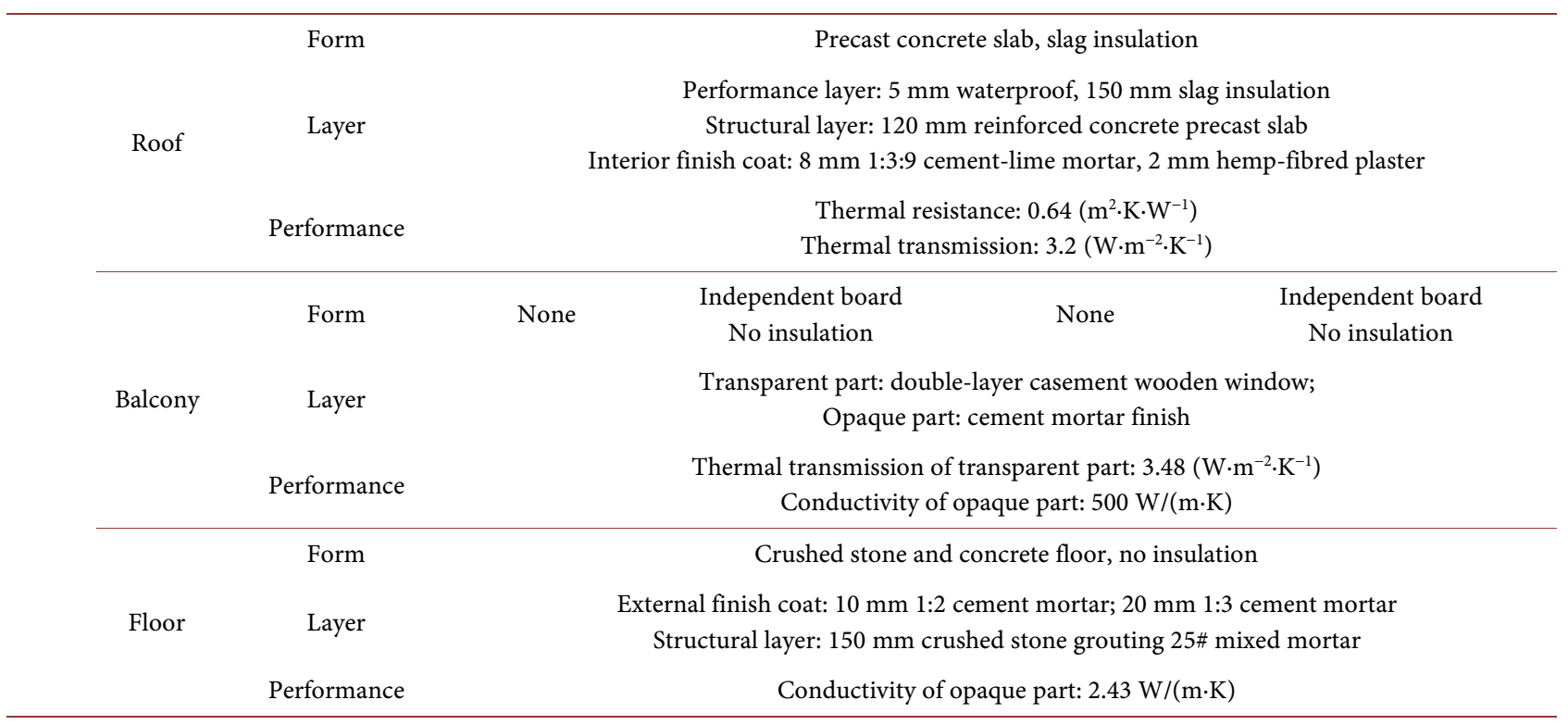

Table 4. The second hierarchical editing layer.

\begin{tabular}{|c|c|c|c|c|}
\hline & Original state & Layer & Approach & Method \\
\hline \multirow{5}{*}{$\sum_{3}^{\bar{न}}$} & \multirow{5}{*}{$\begin{array}{l}\text { Red brick wall without } \\
\text { insulation. } 370 \mathrm{~mm} \text { solid } \\
\text { brick masonry wall } \\
\text { Insufficient thermal } \\
\text { resistance }\end{array}$} & Performance layer & Cavity insulation & $\begin{array}{l}\text { Inject loose or foam thermal insulation materials into the } \\
\text { existing cavity of the wall to increase thermal resistance. } \\
\text { Performance depends on the depth of the wall cavity }\end{array}$ \\
\hline & & External finish coat & $\begin{array}{l}\text { Repair/replace external } \\
\text { finish coat materials }\end{array}$ & $\begin{array}{l}\text { Use paint or stone to replace/repair the external finish coat to } \\
\text { protect the performance layer }\end{array}$ \\
\hline & & & Internal Insulation & $\begin{array}{l}\text { Add gypsum board to internal finish coat to improve thermal } \\
\text { resistance. }\end{array}$ \\
\hline & & $\begin{array}{l}\text { Performance layer \& } \\
\text { External finish coat }\end{array}$ & External insulation & Attach a double-glazing on the inside \\
\hline & & & Ventilated facade & $\begin{array}{l}\text { Attached rigid thermal insulation board and cladding to } \\
\text { external finish coat to improve thermal resistance. }\end{array}$ \\
\hline \multirow{6}{*}{ 紊 } & \multirow{6}{*}{$\begin{array}{c}\text { Single glazing, } \\
\text { Double casement window } \\
\text { Insufficient thermal } \\
\text { performance and poor } \\
\text { sealing }\end{array}$} & \multirow{5}{*}{ Window system } & upgrade & Add double glazing and install on existing window frame \\
\hline & & & $\begin{array}{l}\text { The second } \\
\text { single/double glazing }\end{array}$ & add a single/double glazing inside \\
\hline & & & Replace & Replace window with triple glazing \\
\hline & & & Fixed shading & $\begin{array}{l}\text { Shading devices on the outside of the window, such as } \\
\text { hanging, fixed blinds. }\end{array}$ \\
\hline & & & Adjustable shading & $\begin{array}{l}\text { Adjustable shading devices on the inside or outside of the } \\
\text { window, in the form of movable sun visors, blinds, etc. }\end{array}$ \\
\hline & & Space intervention & Enlarge windows & Enlarge original window and replace with new one \\
\hline \multirow{5}{*}{ 岁 } & \multirow{5}{*}{$\begin{array}{l}\text { performance layer: } \\
\text { insufficient insulation of } \\
\text { precast concrete slab. } \\
\text { Waterproof layer and } \\
\text { leveling layer: insufficient } \\
\text { thermal resistance }\end{array}$} & \multirow{3}{*}{ Performance layer } & Asphalt insulation & $\begin{array}{l}\text { Insulation between rafters and suspended ceiling to increase } \\
\text { thermal resistance. }\end{array}$ \\
\hline & & & Top floor insulation & Prevent thermal loss \\
\hline & & & Flat floor insulation & Additional insulation and waterproof layer on the roof panel \\
\hline & & \multirow{2}{*}{$\begin{array}{l}\text { Performance layer \& } \\
\text { External finish coat }\end{array}$} & Green roof & $\begin{array}{l}\text { Additional insulation layer, waterproof layer, soil and plants } \\
\text { are provided on the roof panel }\end{array}$ \\
\hline & & & Flat to slope roof & $\begin{array}{l}\text { Add insulation on roof panel with hanging tiles to increase the } \\
\text { thermal resistance }\end{array}$ \\
\hline
\end{tabular}




\section{Continued}

\begin{tabular}{|c|c|c|c|c|}
\hline \multirow{3}{*}{ 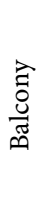 } & Independent board & \multirow{3}{*}{-} & $\begin{array}{l}\text { Balcony board } \\
\text { insulation }\end{array}$ & Add insulation on all balcony surfaces (top and bottom) \\
\hline & $\begin{array}{l}\text { without insulation: } \\
\text { connected to the indoor } \\
\text { floor with thermal bridge }\end{array}$ & & $\begin{array}{l}\text { Remove/replace } \\
\text { balcony }\end{array}$ & $\begin{array}{l}\text { Remove existing balcony and install insulation on the edge of } \\
\text { the floor }\end{array}$ \\
\hline & & & Wrap & Covered with single/double glazing and aluminum frame \\
\hline \multirow{2}{*}{$\stackrel{\check{\circ}}{\stackrel{\circ}{\circ}}$} & $\begin{array}{l}\text { Gravel concrete floor } \\
\text { without performance }\end{array}$ & \multirow[b]{2}{*}{ Performance layer } & $\begin{array}{l}\text { Insulation on top pf } \\
\text { Floor/basement }\end{array}$ & Add insulation on all balcony surfaces (top and bottom) \\
\hline & $\begin{array}{c}\text { layer. } \\
\text { No insulation Sever } \\
\text { thermal loss }\end{array}$ & & $\begin{array}{l}\text { Bottom insulation of } \\
\text { basement ceiling }\end{array}$ & $\begin{array}{l}\text { Add thermal insulation on the bottom of floor slab to } \\
\text { increases thermal resistance }\end{array}$ \\
\hline
\end{tabular}

Table 5. The third hierarchical editing layer.

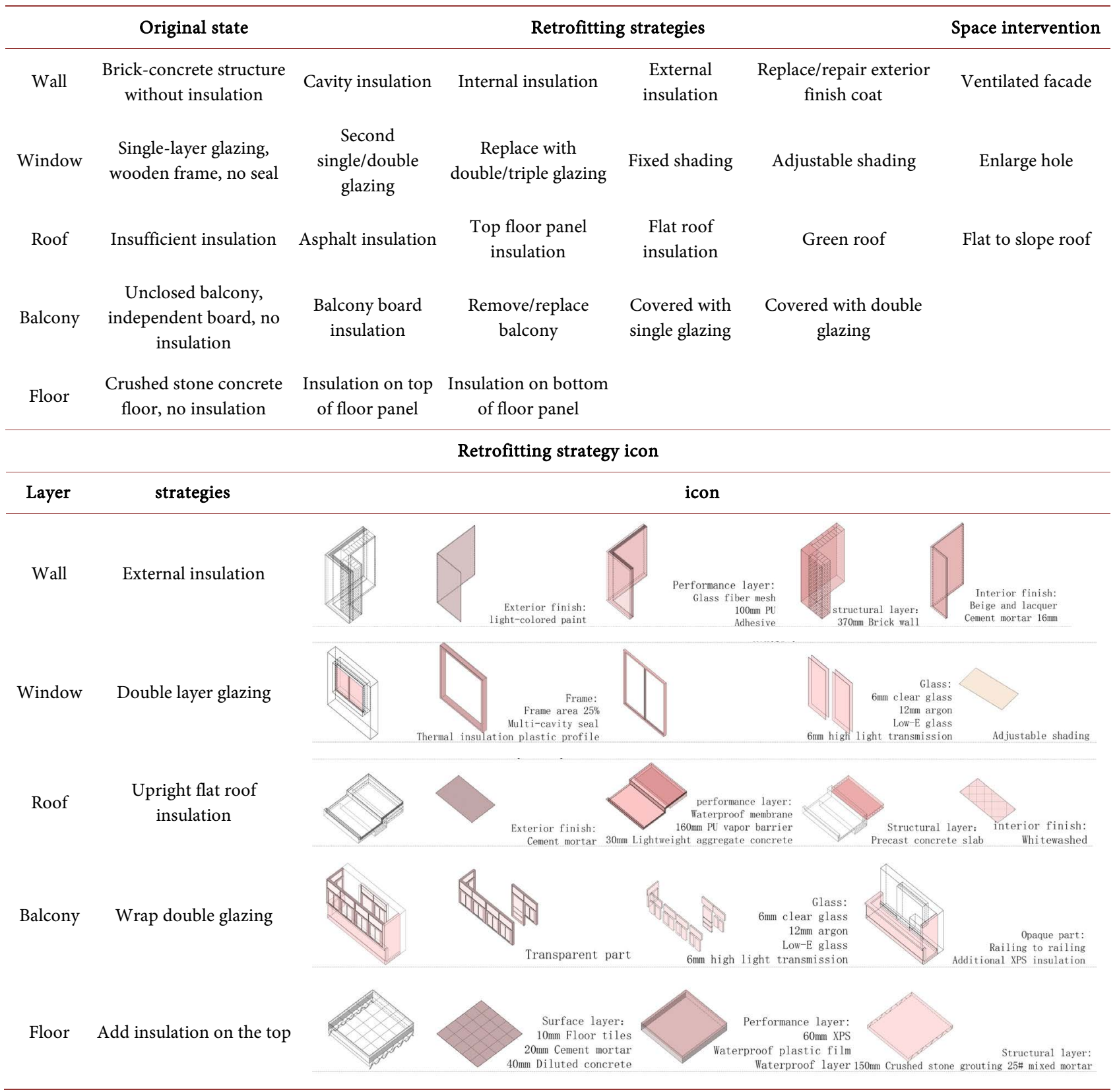


Then, carry a comparison study with the integrity and effectiveness of the combination of individual components retrofitting approaches to form different strategies. The most efficient strategy can be selected according to simulation results to form the third level matrix editing (Table 5). The three hierarchical systems proceed in sequence, systematically formulating an efficient retrofitting strategy to the systematically overall system.

\section{Conclusions}

This paper first divides the envelope system into five parts and several structural layers, and then, sorts out existing residential retrofitting approaches into five types by parts. The hierarchical method is introduced to form a systematical database of existing building retrofitting strategy. On the one hand, it can improve indoor thermal comfort with lower energy consumption. On the other hand, it expands the basic information data of the existing residential envelope system in the cold climate area in China. The database can help designers make retrofitting-related decision and choose retrofitting strategies at early-design-stage efficiently. It also establishes a system for the evaluation and comparison of the building performance.

However, this study only investigated a few typical cities in cold climate area, and the scope of the study needs to be expanded. Therefore, follow-up studies will adopt a variety of data collection methods to more accurately collect the current status of the envelope system, and carry out more interdisciplinary research to improve accuracy. Simulation tools are also introduced to make evaluation and comparison.

\section{Acknowledgements}

This research was partially funded by National Natural Science Foundation of China Project "Research on Design Strategy and Energy Efficiency Optimization of Existing Residential Green Renovation" (51808093). All authors declare no conflicts of interest regarding the publication of this paper.

\section{Conflicts of Interest}

The authors declare no conflicts of interest regarding the publication of this paper.

\section{References}

[1] Jun, W. (2015) China Building Renovation. http://www.chinabrn.cn/index.php/Home/search/olddetails?type=2\&\&id=354

[2] Jiang, Y. (2005) Current Building Energy Consumption in China and Effective Energy Efficiency Measures. Heating Ventilating Air Conditioning, 5, 30-40.

[3] Habraken, N.J. (1972) Supports: An Alternative to Mass Housing. Urban International Press, UK.

[4] Duffy, F. (1990) Measuring Building Performance. Facilities, 8, 17-20. 
https://doi.org/10.1108/EUM0000000002112

[5] Brand, S. (1995) How Buildings Learn: What Happens after They're Built. Penguin Books, New York.

[6] Adaptable Futures (2006). http://adaptablefutures.com/

[7] Fan, Y., Li, Z.B. and Dong, L. (2018) The Environment Quality connection and Regeneration Mode for the Existing Community Residential Building of China. New Architectural, 2, 46-49.

[8] Matsumura, S.C. (2008) Community Regeneration. China Machine Press, Beijing.

[9] Fan, Y., Li, Z.B. and Zhang, Q. (2020) Research on Scientific Framework and Knowledge Base System of Maintenance Regeneration on Existing Residential Buildings. Time+ Architecture, 1, 6-9.

[10] Suo, J., Zhou, Q. and Fan, Y. (2018) Thoughts on the Practice and Existing Problems of Urban Housing Quality Improvement in China. Journal of Human Settlements in West China, 33, 1-5.

[11] Carletti, C., Sciurpi, F. and Pierangioli, L. (2014) The Energy Upgrading of Existing Buildings: Window and Shading Device Typologies for Energy Efficiency Refurbishment. Sustainability, 6, 5354-5377. https://doi.org/10.3390/su6085354

[12] Leskovar, V.Z. and Premrov, M. (2012) Influence of Glazing Size on Energy Efficiency of Timber-Frame Buildings. Construction and Building Materials, 30, 92-99. https://doi.org/10.1016/j.conbuildmat.2011.11.020

[13] Cui, L.Q. (2007) Research on Energy-Saving Reform of Window for Existing Residential Buildings in Handan City. MA Thesis, Hebei University of Engineering, Hebei.

[14] Zhu, N. (2017) Research on the Reconstruction Technology of Batch Assembly of Residential Houses in Old Urban Districts. MA Thesis, Tsinghua University, Beijing.

[15] Xu, C.T. (2008) Influence of External Enclosure Structure of the Residential Building to the Indoor Thermal Environment and Building Energy Consumption. MA Thesis, Chongqing University, Chongqing.

[16] Peuhkuri, R., et al. (2011) Guidelines for the Use of Building Physical Modelling Methods and Tools in the Development of Sustainable Refurbishment Technologies for External Walls. SUSREF Deliverable2.2.

https://www.semanticscholar.org/paper/Deliverable-\%3A-D-2-.-2-Title-\%3A-Guide lines-for-the-of-Peuhkuri-Hol\%C3\%B8s/5e43f427f2a674cbaa7e5f9d7d30d0171a010 4b4\#paper-header

[17] Liang, X.C. (2010) Research on Energy-Efficiency Renovation of Urban Existing House. Housing Science. 30, 38-40.

[18] Liu, J.R. (2010) Study on Energy Efficiency Renovation of Exiting Residential Buildings in Heating Areas in North China. China Educational Technology \& Equipment, 30, 78-79.

[19] Tommerup, H. and Svendsen, S. (2006) Energy Savings in Danish Residential Building Stock. Energy and Buildings, 38, 618-626. https://doi.org/10.1016/j.enbuild.2005.08.017

[20] Arslan, O. and Kose, R. (2006) Thermo-Economic Optimization of Insulation Thickness Considering Condensed Vapor in Buildings. Energy and Buildings, 38, 1400-1408. https://doi.org/10.1016/j.enbuild.2006.02.012

[21] Verbeeck, G. and Hens, H. (2005) Energy Savings in Retrofitted Dwellings: Eco- 
nomically Viable. Energy and Buildings, 37, 747-754. https://doi.org/10.1016/j.enbuild.2004.10.003

[22] Siller, T. (2007) Long-Term Energy Savings and Greenhouse Gas Emission Reductions in the Swiss Residential Sector. Energy Policy, 35, 529-539.

https://doi.org/10.1016/j.enpol.2005.12.021

[23] Häkkinen, T. (2012) Systematic Method for the Sustainability Analysis of Refurbishment Concepts of Exterior Walls. Construction and Building Materials, 37, 783-790. https://doi.org/10.1016/j.conbuildmat.2012.07.084

[24] Konstantinou, T. (2014) Facade Refurbishment Toolbox: Supporting the Design of Residential Energy Upgrades. Architecture and the Built Environment.

[25] Wang, P.P. (2017) Study on Energy-Saving Design for Passive House Envelope in Cold Region. MA Thesis, Southwest Jiaotong University, Chengdu.

[26] Knaack, U., Klein, T., Bilow, M., and Auer, T. (2007) Façades Principles of Construction. Birkhäuser, Basel.

[27] Giebeler, G. (2009) Refurbishment Manual: Maintenance, Conversions, Extensions. Birkhäuser, Basel. https://doi.org/10.11129/detail.9783034614337

[28] Tadeu, A.J.B. and Mateus, D.M.R. (2001) Sound Transmission through Single, Double and Triple Glazing. Experimental Evaluation. Applied Acoustics, 62, 307-325. https://doi.org/10.1016/S0003-682X(00)00032-3

[29] Yuan, T.J. (2010) Research on Energy-Saving Renovation Technology of Enclosure Structure of Existing Residential Buildings in Jinan City. MA Thesis, Shandong Jianzhu University, Jinan.

[30] McMullan, R. (2002) Environmental Science in Building. Palgrave, Basingstoke.

[31] Baetens, R., Jelle, B.P. and Gustavsen, A. (2011) Aerogel Insulation for Building Applications: A State-of-the-Art Review. Energy and Buildings, 43, 761-769. https://doi.org/10.1016/j.enbuild.2010.12.012

[32] Ministry of Housing and Urban-Rural Development of the People's Republic of China (2014) Vacuum insulation board for building. JG/T 438-2014, Ministry of Housing and Urban-Rural Development of the People's Republic of China, Beijing.

[33] Koebel, M.M., Manz, H., Emanuel Mayerhofer, K. and Keller, B. (2010) Service-Life Limitations in Vacuum Glazing: A Transient Pressure Balance Model. Solar Energy Materials and Solar Cells, 94, 1015-1024. https://doi.org/10.1016/j.solmat.2010.02.003

[34] Chen, R.G., Chen, Y.L., Liu, X.Z. and Wu, W.Q. (2015) Advancement of Phase Change Materials and its Application in Building Energy Efficiency. Materials Reports, 29, 51-57. 